$1-1-1964$

\title{
The market for industrial lumber in West Virginia and in surrounding states
}

Donald E. Nelson

Follow this and additional works at: https://researchrepository.wvu.edu/ wv_agricultural_and_forestry_experiment_station_bulletins

\section{Digital Commons Citation}

Nelson, Donald E., "The market for industrial lumber in West Virginia and in surrounding states" (1964). West Virginia Agricultural and Forestry Experiment Station Bulletins. 502.

https://researchrepository.wvu.edu/wv_agricultural_and_forestry_experiment_station_bulletins/467 @ WVU. It has been accepted for inclusion in West Virginia Agricultural and Forestry Experiment Station Bulletins by an authorized administrator of The Research Repository @WVU. For more information, please contact ian.harmon@mail.wvu.edu. 
West Virginia University Libraries

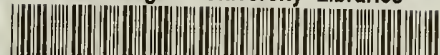

.|.

$\begin{array}{lll}3 & 08021008961379\end{array}$ 
Digitized by the Internet Archive in 2010 with funding from

Lyrasis Members and Sloan Foundation

http://www.archive.org/details/marketforindustr502nels 
BULLETIN 502

December 1964

The Market for Industrial Lumber

in West Virginia

And in Surrounding States

\section{AG-ENG LIBRARY \\ WEST VIRGINIA UNIVERSITY.}




\section{THE AUTHORS}

Authors of The Market for Industrial Lumber in West Virginia and in Surrounding States are D. E. Nelson and W. H. Reid. Mr. Nelson, instructor in Wood Technology, Division of Forestry, West Virginia University, is now working on his doctorate in forestry at the University of Michigan, Ann Arbor. Mr. Reid, formerly Assistant Professor of Forest Utilization, Division of Forestry, is now with Forest Products Marketing Branch, Division of Forest Economics and Marketing Research. USDA, Forest Service, Washington, D. C.

West Virginia Universiti

Agricultural Experiarext Station

College of Agriculture, Forestry, and Hoxe Economics

A. H. VanLandinghai, Director

Morgantow 


\section{CONTENTS}

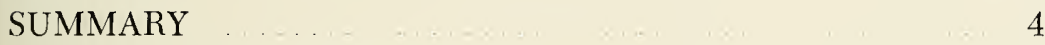

The National Picture $\quad 5$

INTRODUCTION TO THE STUDY 9

SOURCES OF COMPARATIVE DATA 10

NUMBER OF FIRMS ... . . . . $\quad 11$

TYPES OF FIRMS ....... 12

Flooning and Dimension $\ldots \ldots 12$

MILLWORK …........ 13

Prefabricated Wooden Buildings 14

Containers $\ldots \ldots \ldots \ldots \ldots \ldots \ldots$

FurNiture . . . . . . . . 15

Wood Products Not Elsewhere Classified 16

DISCUSSION

CONCLUSIONS $\ldots \ldots \ldots \ldots \ldots$ 


\section{SUMMARY}

Secondary wood-using firms in Vest Virginia were generally smalleı and fewer in number than those in surrounding states. The Nine-State region covered by this study included West Virginia and eight surrounding states. The eight states are Pennsylvania, North Carolina, Massachusetts, Ohio, New Hampshire, Virginia, Maine, and Vermont. West Virginia had the smallest number of secondary wood-using firms in this region. Only three West Virginia firms were large enough to employ more than 100 workers. Elsewhere in the region, 238 firms employed more than 100 workers.

The firms selected for this study were those whose industrial classification numbers indicated they were large users of wood.

West Virginia firms experienced little difficulty procuring lumber, because the volume of lumber produced in WVest Virginia greatly exceeded the volume used in secondary manufacturing.

The industries surveyed are listed below according to number of workers employed in West Virginia firms:

\section{Industry Group}

20 Furniture

8 Flooring and Dimension

4 Containers

6 Others (mostly pallets)

2 Millwork

40
Number of Workers

925

327

160

108

21

1,541

A total of over 1,500 workers was employed in these 40 firms. More than 40 million board feet of lumber was consumed in production.

Twenty furniture firms employed the largest number of workers of those West Virginia wood-using industries listed. Compared to surrounding states, however, West Virginia's furniture industry is small. A single furniture firm in Virginia employed 3,000 workers and used more lumber than the entire secondary wood-using industry in West Virginia. A single flooring firm in Ohio used more lumber than all eight West Virginia flooring and dimension firms. The four manufacturers of containers in West Virginia used less lumber than a single Virginia container firm.

Five W'est Virginia pallet manufacturers employed about 100 workers; the largest consumed about 4.5 million board feet of lumber, half of which was out-of-state softwood. This size pallet operation appears to be 
competitive in size with others in the region. However, the large volume of softwood lumber used would perhaps favor plant location in Virginia or North Carolina.

West Virginia has good quality hardwood lumber, which helps account for the relative lack of lumber purchasing problems by the few wood-using firms located within the State. It is a policy of the State government to encourage wood-using industries. Firms which consider locating in West Virginia will find that the available supply of hardwood lumber offers advantages of raw material. The State is surrounded by large, successful wood-using firms, many using West Virginia lumber.

\section{THE NATIONAL PICTURE}

Former studies (1948) of wood used in manufacturing provide the background information needed to place West Virginia and the NineState area in their proper national perspective. This information is used because more recent national data is not available, and because our 1960 study covered only West Virginia and nearby states.

Containers, millwork, furniture, and flooring are the manufactured products that required the most lumber, considering both hardwood and softwood combined. Furniture firms consumed the most hardwood lumber, followed by container manufacturers, flooring manufacturers, and millwork firms. The manufacture of these four products in $194 \mathrm{~S}$ required 3.7 million board feet of hardwood lumber; this amounted to 76 per cent of all hardwood lumber used in manufacturing.

Table 1 summarizes lumber used in manufacturing in 1948, by state and product. Hardwood lumber production and total lumber production are given for each state. Unfortunately, softwoods and hardwoods were grouped in the products by state classification. However, total hardwood lumber used in manufacturing is given for each state and for the nine states combined.

Several important generalizations for 1948 are evident from Table 1 :

1. Of the 35 billion board feet of lumber produced, about 12 billion board feet was used in manufacturing.

2. Less than 5 billion board feet used in manufacturing was hardwood lumber.

3. Three-fourths of the hardwood lumber, 3.7 billion board feet, was manufactured into four products: furniture, containers, flooring, and millwork.

4. Nearly one-third ( 1.5 billion board feet) of the hardwood lumber used in manufacturing was used within the Nine-State area. 


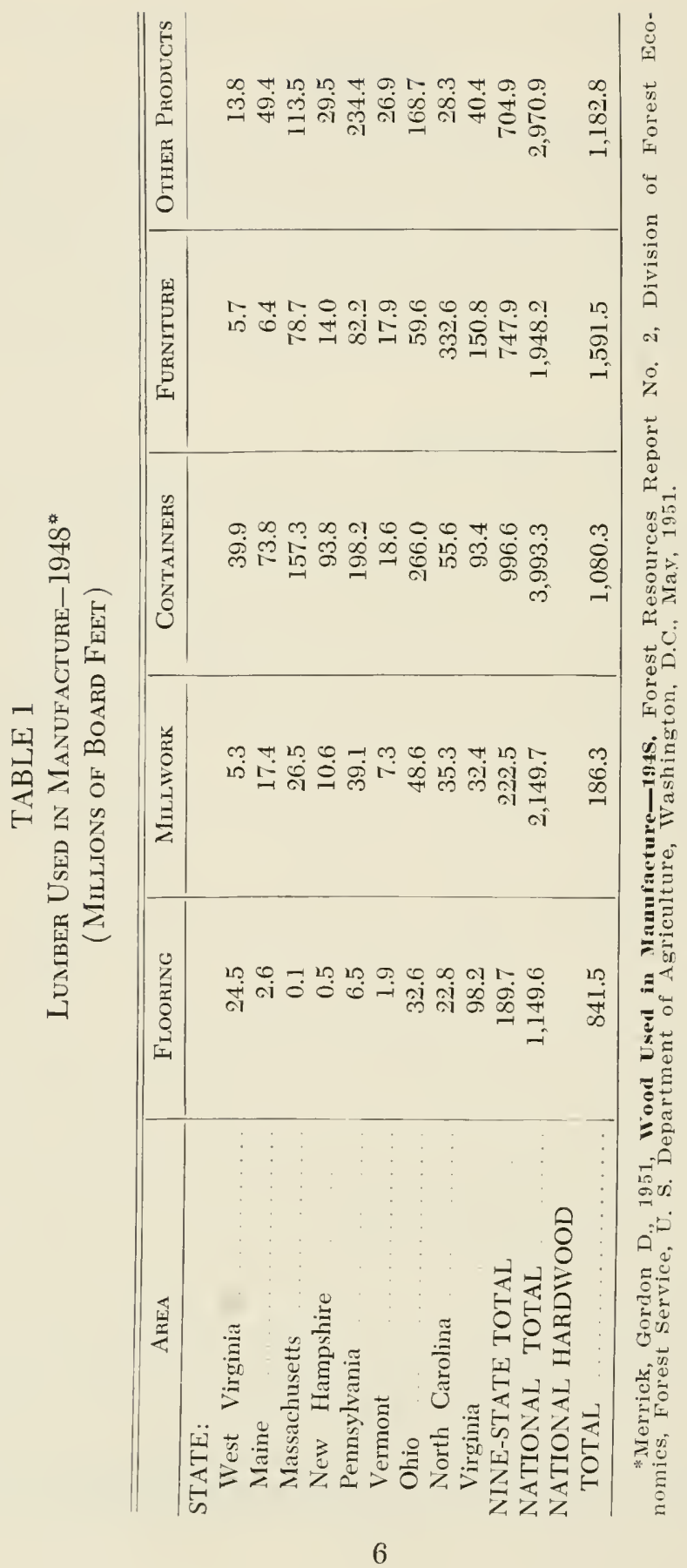




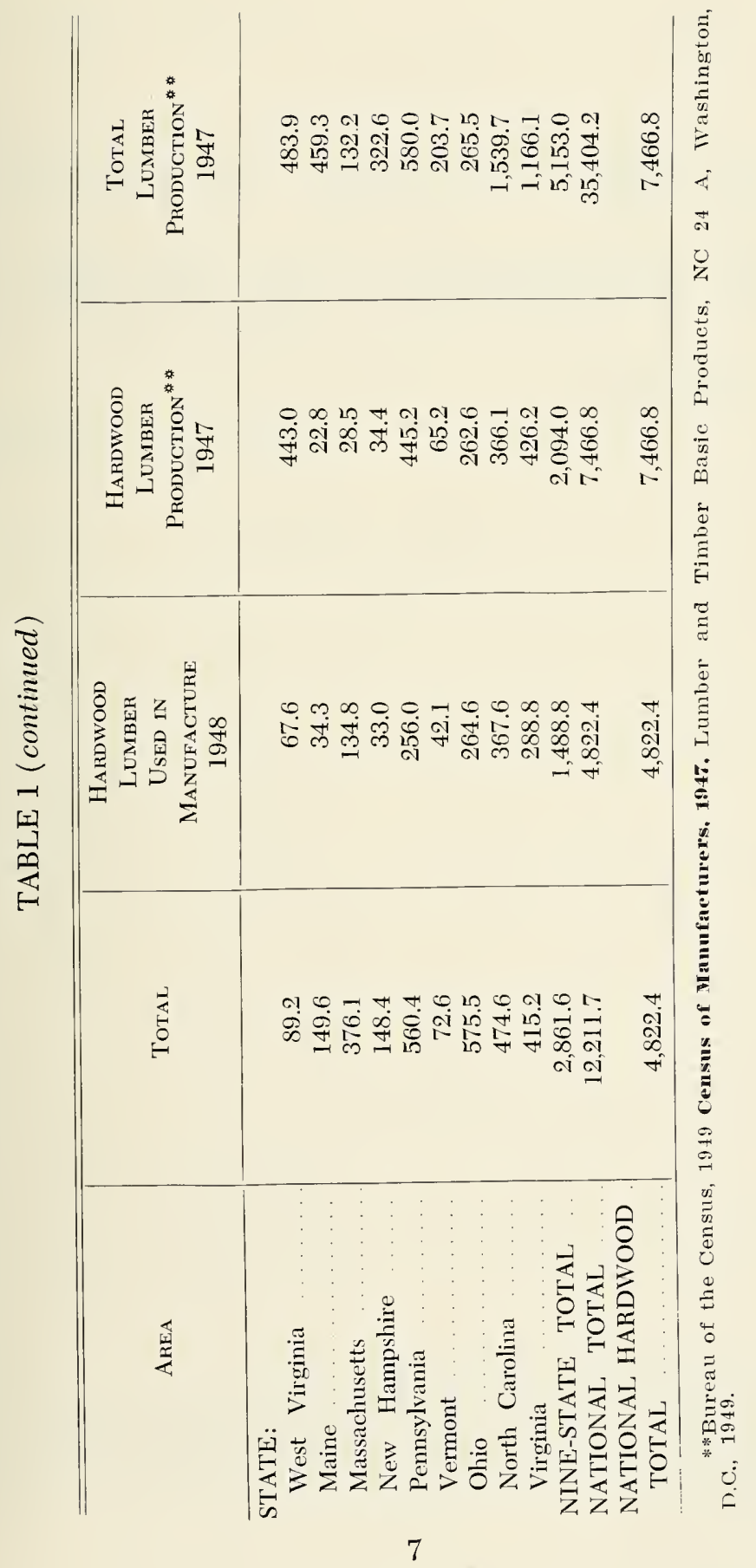


5. Five states manufactured over 100 million board feet of hardwood lumber products. They are, in order: North Carolina, Virginia, Ohio, Pennsylvania, and Massachusetts.

6. Five states produced over 100 million board feet of hardwood lumber. They are, in order: Pennsylvania, West Virginia, Virginia, North Carolina, and Ohio.

In the Nine-State area, only Pennsylvania produced more hardwood lumber than West Virginia. But five states manufactured more lumber products. In the Nine-State area, West Virginia produced the smallest amount of the most important product made from hardwood-furniture. Consequently, in West Virginia lumber is not being put to best use. Nationally, furniture firms consumed more hardwood lumber than any industry group, and furniture has a high-value per board foot of raw material. 


\section{The Market for Industrial Lumber in West Virginia and in Surrounding States}

D. E. NELSON and W. H. REID

\section{Introduction to the Study}

This study compares selected wood-using firms in West Virginia with similar firms in other Northeastern states, and Ohio, North Carolina, and Virginia. The data gathered comprised West Virginia's contribution to the regional marketing project NEM-24, Phase II, which also included Maine, Massachusetts, New Hampshire, Pennsylvania, and Vermont. ${ }^{1}$ An adjunct study including Ohio, North Carolina, and Virginia provided additional information about nearby states outside the Northeast region. This information, combined with the Northeast regional study, provided an excellent opportunity to compare IVest Virginia's secondary wood-using industry to industry in surrounding states.

As purchases by industry are one link in the lumber marketing chain, interviews with management personnel yield information on this aspect of marketing.

Those firms surveyed in 1960 in West Virginia were the most important users of lumber. The same industry groups accounted for over 80 per cent of the lumber used in manufacturing in West Virginia in $1948^{2}$ (the latest year for which information by states is available). According to this source, container, flooring, furniture, and millwork firms used 75 million board feet of the 89 million board feet used by all firms in West Virginia in 1948.

In all states, Standard Industrial Classification (SIC) numbers were used. The four-digit SIC numbers of the industries surveyed are listed at the top of page 10 .

${ }^{1}$ Whitmore, Roy E. and others, 1963, Marketing of Lumber in the Northeast, Phase II-Lumber Purchases by Wood Products Manufacturers, Vermont Agricultural Experiment Station, Bulletin 635, June, 1963.

${ }^{2}$ Merrick, G. D., 1951, Wood Used in Manufacturing-1948, Forest Resource Report No. 2, U.S. Department of Agriculture, Forest Service, Washington, D.C., May, 1951. 
Flooring and dimension stock 2426 Hardwood dimension and flooring

Millwork

Prefab structures

Containers

Furniture

Others (including pallets)

2431 Millwork plants

2433 Prefabricated w o o d e n buildings and structural members

2441 Nailed and lock corner wooden boxes and shook

2442 Wirebound boxes and crates

2445 Slack and tight cooperage

2511 Wood household furniture, except upholstered

2512 Wood household furniture, upholstered

2521 Wood office furniture

2541 Wood partitions, shelving, lockers, and office and store fixtures

2499 Wood products not elsewhere classified

An interview with all West Virginia firms listed under the above SIC numbers was intended. Unfortunately no complete list of West Virginia firms by SIC numbers exists, and some firms listed are probably incorrectly classified. SIC industrial classification is based upon the primary product produced, therefore, it excludes firms which use lumber but do not produce a wooden product. An example of this is the use by foundries of lumber bottoms or the use of lumber in farm machinery.

Therefore, the survey did not include all the West Virginia firms which use lumber. Neither did all firms listed purchase lumber. Some produced lumber for their own consumption, while others purchased dimension stock. Many upholstery firms bought assembled wooden frames rather than lumber. Manufacturers of rail fence used logs as their raw material, rather than lumber.

This study presents West Virginia data, and compares West Virginia practices with those of surrounding states for which a similar survey has been conducted. The following section contains a brief introduction to this comparative data.

\section{Sources of Comparative Data}

The two studies listed below directly relate to the West Virginia study. Identical questionnaires were used throughout. Therefore, the data is comparable. 
1. The Northeastern States survey was based upon a list by state of firms in the above SIC groups, as furnished by the Bureau of Old Age Survivors Insurance (BOASI). This listed all firms paying into employees' social security, and the total employment of each firm. West Virginia, Vermont, and Maine attempted to interview all the firms on their state list. Massachusetts, New Hampshire, and Pennsylvania interviewed a sample of the firms listed, but proportionately more of the large firms. The results of this survey are contained in the regional publication for NEM-24, Phase II. ${ }^{3}$

2. Three important wood-using states outside of the Northeastern egion were surveyed in an adjunct study to NEM-24, Phase II, Woodssing firms were selected at random from manufacturing directories of zach state.

Results of this adjunct study will be published by the Northeastern Forest Experiment Station. ${ }^{5}$

\section{Vumber of Firms}

West Virginia had the fewest number of firms in the selected SIC roups of any state in the Nine-State area. Number of firms is given beow:

\section{State}

Pennsylvania

North Carolina

Massachusetts

Ohio

New Hampshire

Virginia

Maine

Vermont

West Virginia

Total number of firms in selected SIC groups
Number of Firms

614

391

333

238

112

93

85

70

40

1,976

'Whitmore, Roy A., and others, 1963, Marketing of Lumber in the Northeast, hase II-Lumber Purchases by Wood Products Manufacturers, Vermont Agricultural xperiment Station, Bulletin 635, June, 1963.

${ }^{4}$ Virginia Chamber of Commerce, 1961, Industrial Directory of Virginia Manucturing and Mining, Dec., 1961, pp. 58-65.

North Carolina Department of Labor, 1960, North Carolina Directory of Manucturing Firms, 1960, pp. 411-616.

Ohio Department of Industrial Relations, 1961, Directory of Ohio Manufacturers, ). 363-707.

${ }^{5}$ (Tentative Citation) Lindell, Gary R., 1965, Marketing West Virginia Lumber Users in Other States, Northeastern Forest Experiment Station, Upper Darby, Pa. 
Of the 1,976 firms, 256 employed in excess of 100 workers each. Only three of these large firms were in West Virginia. West Virginia firms were both few in number, and characteristically small in size.

\section{Types of Firms}

\section{FLOORING AND DIMENSION-SIC \#2426}

Eight West Virginia firms were classified as flooring and dimension producers. There were 68 similarly classified firms in the rest of the Nine-State area. Six of the West Virginia firms produced mostly flooring as their main product. Some other West Virginia firms also produced considerable volumes of flooring and dimension, but not as their main product. The flooring produced by these firms is, therefore, not included in the totals for SIC $\# 2426$. The SIC numbers of those firms in IVest Virginia producing flooring as a minor product are:

\#2421, Sawmills and Planing Mills

\#2431, Millwork Plants

*2411, Logging Camps and Logging Contractors

\#2499, Wood Products Not Elsewhere Classified

The eight flooring and dimension firms played an important role in West Virginia's secondary wood manufacturing in 1960. They employed 327 workers; second only to the furniture group SIC $\# 2511,2512,2521$, and 2541. They converted over 14 million board feet of lumber into flooring and dimension. This industry represented the largest single manufacturing use of lumber in West Virginia, and produced about 30 per cent of the total flooring and dimension produced in the Northeast area.' But compared to the hardwood producing states of Ohio, North Carolina, and Virginia, the 14 million board feet of lumber going into flooring and dimension in West Virginia is small. One large North Carolina firm, for example, manufactured 12 million board feet of lumber into dimension in 1961; several Virginia flooring firms each consumed 10 million board feet of lumber, and one Ohio flooring plant consumed 12 million board feet. The largest West Virginia producer consumed only 3 million board feet.

Nearly half of the lumber manufactured into flooring and dimensior in West Virginia was produced by the manufacturer. This type of

${ }^{6}$ Personal Letter from Koder M. Collison, October 7, 1963, Department of Com merce, State Capital, Charleston, West Virginia.

TWhitmore, Roy A. and others, 1963, Marketing of Lumber in the Northeast thase II-Lumber Purchases by Wood Products Manufacturers, Vermont Agricultura Experiment Station, Bulletin 635, June 1963. 
vertical integration with sawmills was common in flooring and dimension, but less common in the other classifications. Considerable vertical integration was also present in the wooden container industry in West Virginia. Elsewhere in the Nine-State area, the flooring and dimension industry purchased a larger proportion of the lumber they used.

Most of the lumber purchased by West Virginia flooring and dimension firms was rough hardwood, much of which had been air-dried. Surprisingly, class 1 (No. 1 common and better) lumber was purchased almost exclusively for flooring and dimension, except for a manufacturer of truck-bed flooring in West Virginia, who purchased all class 2 (No. 2 sommon and poorer) lumber. Other firms in the Nine-State area purshased considerable class 2 lumber for flooring and dimension.

All lumber purchased by manufacturers of flooring and dimension in West Virginia was purchased directly from the lumber manufacturer ather than through an intermediary. Nearly all was purchased from IVest Virginia sawmills, the only exception was about 3 per cent of the otal which came from Kentucky. As would be expected, lumber was nostly purchased and shipped in truckload lots.

West Virginia firms indicated present and past lumber purchasing difficulties. Two firms listed inaccurate manufacturing of the lumber as he major present difficulty. Other past difficulties were concerned with zrade, species, and seasoning condition. Switching suppliers was given jy most firms as the best solution to purchasing difficulties.

Conformance to specifications was the major factor influencing the uurchaser's choice of suppliers. Delivery assurance and price were the ther factors mentioned. West Virginia flooring and dimension firms which purchased lumber relied on as few as 10 suppliers to as many as 18. Large firms in North Carolina, Ohio, and Virginia each dealt with ver 100 suppliers.

\section{VILLWORK-SIC \#2431}

Only two millwork firms were operating in West Virginia, compared o 472 in the rest of the Nine-State area. Other West Virginia firms proluce some millwork products in addition to their main products. Most of hese additional millwork producers are listed under SIC \#2511 or 2512, sumber Yards and Building Materials Dealers, and therefore are not inluded in the survey.

The two West Virginia millwork firms employed 20 workers, and urchased all of the 1.5 million board feet of hardwood lumber they nanufactured into millwork. Half of the lumber was purchased through narket intermediaries; all was rough, dry, and class 1 . Ten per cent came rom Pennsylvania, and the rest was local lumber. 
West Virginia millwork firms experienced past and present purchasing difficulties both in inaccurately manufactured lumber, and lumber which did not conform to grade.

Nationally, and within the Nine-State area, millwork is primarily manufactured from softwoods. Individual millwork firms vary in size; the largest millwork firms were in Virginia and Ohio. Each requires up to 10 million board feet of lumber per year. The two West Virginia firms use only hardwood, and they are rather small in comparison, using less than 2 million board feet of lumber per year between them.

\section{PREFABRICATED WOODEN BUILDINGS-SIC $\# \mathbf{2 4 3 3}$}

There were 30 manufacturers of prefabricated wooden buildings in the Nine-State area. With the exception of hardwood flooring, most housing components are made from softwood. West Virginia is, therefore, not an ideal location for a prefabricated building industry, from the standpoint of local lumber. But much Western and Southern softwood lumber is sold in West Virginia for use in housing. A Pennsylvania prefabricator, for example, sells pre-cut houses throughout West Virginia.

One drawback to establishing this industry in West Virginia is that competitors in nearby states are established on a large scale. One firm in Virginia employed 500 workers, and purchased 28 million board feet of lumber in 1961. Based on an estimated 7,000 board feet per house, this firm manufactures about 4,000 houses per year. Most of the lumber used by this firm was local Virginia softwood.

\section{CONTAINERS_SIC \#2441, 2442, and 2445}

Four firms in West Virginia were classified under the above SIC numbers. Three were SIC \#2441, Wooden Boxes and Crates, and the other was SIC \#2442, Wirebound Boxes and Crates. There was no SIC \#2445, Slack and Tight Cooperage.

The four firms employed 160 workers, and purchased over 10 million board feet of lumber, mostly West Virginia hardwood. One firm, located a short distance from Virginia, purchased most of its lumber in Virginia. A small amount of softwood lumber was used by these firms. One firm was vertically integrated with a sawmill, and obtained most of the lumber required directly from the mill.

The Nine-State area had 136 firms which produced containers; many of these firms were in Pennsylvania. Within the nation, container firms are the largest users of wood in manufacturing, but softwood lumber is primarily used. Even so, large volumes of low-grade hardwood lumber are used in containers.

Virginia had eight firms producing containers. The largest employed 375 workers and manufactured nearly 13 million board feet of 
lumber into containers in 1961. Most of the lumber used by this firm was hardwood lumber purchased from Virginia sawmills.

The purchasing problems of West Virginia container manufacturers related primarily to inaccurately manufactured lumber. The most common solution was to switch suppliers.

The container industry is able to utilize low-grade lumber, with the exception of slack and tight cooperage, which required high-grade bolts. Wooden containers are still widely used, but competitive materials are naking inroads. There is an indication that consumption of lumber for containers is decreasing nationally, thus the outlook for expansion of this ndustry is not promising.

\section{FURNITURE-SIC \#2511, 2512, 2521, AND 2541}

IVest Virginia had a total of 20 firms in the four SIC classifications or furniture. Of the wood manufacturing industries in IVest Virginia, urniture firms employed the most workers, 925. The only three woodising firms in the entire State employing more than 100 workers were urniture manufacturers, although the majority of the furniture plants vere small.

Total lumber purchased by West Virginia furniture producers was bout 6 million board feet, of which nearly two-thirds was purchased by he three large firms. This volume of lumber for furniture is minor comared to surrounding states. North Carolina had 96 firms in the over 100 mployee class. A single North Carolina firm employed 600 workers and onverted over 13 million board feet of lumber into furniture. One Vir;inia firm employed 3,000 workers and converted over 55 million board eet per year into furniture. The Northeast region had 478 furniture irms, and Ohio, North Carolina, and Virginia had an additional 462. hus, West Virginia, situated in the heart of the hardwood-lumber proucing and furniture-producing area, does not produce significant olumes of furniture.

West Virginia furniture manufacturers purchased mostly rough, airried, hardwood lumber, about equally divided between class 1 and lass 2 lumber. Kentucky, Ohio, and Pennsylvania supplied a small olume of the hardwood lumber, but most lumber was purchased directfrom West Virginia sawmills. One firm produced some of its own ardwood lumber.

Accuracy of manufacturing was the major purchasing difficulty for veral firms. Another major difficulty was assurance of delivery. Switchig lumber suppliers and paying a premium rate for good quality lumber ere the most common solutions to lumber purchasing difficulties.

Several large furniture firms in North Carolina indicated that they urchased from 10 to 20 per cent of their raw lumber from West Vir- 
ginia. Small firms in North Carolina normally bought local lumber. The North Carolina firm mentioned earlier, which used over 13 million board feet per year, purchased 15 per cent of its lumber in West Virginia. West Virginia provided the best delivery and conformance to specifications, according to this firm's buyer.

Several large Ohio firms in the survey purchased some out-of-state lumber from Pennsylvania and New York. One buyer of lumber for upholstered frames indicated that he had no contacts in WVest Virginia, and asked for a list of IVest Virginia lumber producers. He mentioned a lack of advertising by West Virginia lumber producers as his reason for not knowing about this source.

The Virginia firms surveyed relied quite heavily upon West Virginia lumber. One firm, using 3 million board feet annually, purchased 60 per cent from West Virginia, although the largest Virginia furniture firm purchased its lumber from Virginia, North Carolina, and Maryland.

Furniture is the most important product manufactured from hardwood lumber in the Nine-State area. Furniture manufacturers purchased 44 per cent of the lumber sold to manufacturers. Thirty-seven per cent of the Northern New England' hardwood lumber sold to manufacturers was purchased by furniture manufacturers."

\section{WOOD PRODUCTS NOT ELSEWHERE CLASSIFIED-SIC $\# 2499$}

Six firms which used lumber in West Virginia were classified as SIC \#2499; they employed 108 workers. This classification refers to industries not classified elsewhere by the SIC number. SIC $\# 2499$ does not include all the remaining West Virginia wood-using firms. It simply refers to a group of firms important enough to be included in the survey. Five of these firms produced pallets; the sixth produced laminated chopping blocks. For discussion, this category will be concerned only with the pallets.

Pallet manufacturers purchased about equal volumes of West Virginia hardwoods, and softwoods from North Carolina and the West Coast. Small quantities of hardwood lumber were purchased from Maryland and Ohio. Total lumber used was nearly 9 million board feet. The softwoods purchased were all class 1 . The hardwoods were divided between class 2 and ungraded. The softwoods were dry and dressed, while the hardwoods were green and rough. The West Coast softwoods werc

"The Northern New England Region included Maine, Massachusetts, New Hampshire, and Vermont.

"Christensen, IV. IV., and others, 1962, Marketing of Lumber Produced by Saw. mills in the Northeast-Phase I, West Virginia University Agricultural Experimen Station, Bulletin 478, June, 1962. 
urchased through a market intermediary; the remaining lumber was irchased from the manufacturer. The major lumber purchasing prob$n$ of pallet manufacturers was conformance to specifications.

Nine other firms in West Virginia were classified as SIC \#2499, it these were not included in the survey because they did not use lumr as a raw material. Most of these firms were small operations producg rustic fence, locust insulator pins and bushings, and tool handles. The w material used was mostly round bolts or entire logs, rather than mber.

Pallet production has been steadily increasing as firms in many lines opt pallets for materials-handling. West Virginia firms vary in size $\mathrm{m} 10$ to 50 employees, and in lumber consumption from 250,000 ard feet to 4.5 million board feet per year.

\section{Scussion}

West Virginia has an established reputation as a producer of highIality primary wood products, the most important being Appalachian rdwood lumber. Few firms have established secondary manufacturing cilities within the State. Those which have are, for the most part, small erations which attempt to compete with industrial giants in nearby ites. While West Virginia firms had few lumber procurement probns, factors other than availability of lumber evidently discouraged condary wood-using firms from locating within the State.

In the period following the field survey, several new wood-using ms have been established in West Virginia. West Virginians are beming enthusiastic about the possibilities for enlarging the State's secdary wood-using industry. A Governor's Advisory Committee on Wood ilization was appointed, and in 1961 the first Governor's Conference Wood Utilization was held. The Honorable W. W. Barron, Governor, ened the conference with these words:

This conference is the first step in the development of what we think will be one of the greatest boosts the West Virginia economy has had in recent years. ...

The possibilities for industrial progress in this field are so high and so wide in scope that they cause us to wonder why action such as this planning conference wasn't taken a long time ago. By bringing together varied interests concerned with developing a strong wood-based economy, we intend to show the rest of the nation and the world that West Virginia has the initiative and resourcefulness to solve its own problems. ${ }^{10}$

${ }^{10}$ Proceedings of the Governor's Conference on Wood Utilization, Civic Center, arleston, West Virginia, Sponsored by the Governor's Advisory Committee on ood Utilization, Nov. 30-Dec. 2, 1961. p. 1.

\section{(Turn page for conclusions)}




\section{Conclusions}

The major secondary wood-using firms in West Virginia were surveyed, and compared to their counterparts in surrounding states. As a rule, West Virginia firms were fewer in number and smaller in size than similar firms in nearby states.

West Virginia firms experience little difficulty procuring lumber for production. Any difficulties were easily overcome by switching suppliers. Surrounding states used considerable volumes of West Virginia hardwoods in producing flooring and dimension, millwork, pre-fabricated structures, containers, furniture, and pallets.

The enthusiasm for wood-using industry generated within the State has resulted in several new plants being established since this study was completed. Indications are that more will follow. 





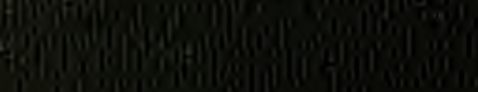

(u)

jo

(1)

ongong

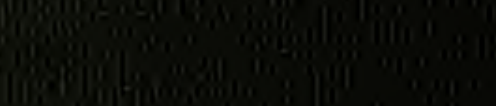

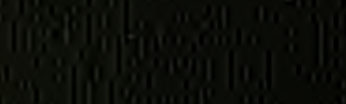

1) 